\begin{tabular}{|c|c|c|}
\hline & Cell Physiol Biochem 2012;30:489-498 & \\
\hline hemistr & $\begin{array}{l}\text { DOI: 10.1159/000341432 } \\
\text { Published online: July 13, } 2012\end{array}$ & $\begin{array}{l}\text { O) } 2012 \text { S. Karger AG, Basel } \\
\text { www.karger.com/cpb }\end{array}$ \\
\hline & Accepted: May 18, 2012 & $1015-8987 / 12 / 0302-0489 \$ 38.00 / 0$ \\
\hline
\end{tabular}

\title{
Ischemia and Reperfusion Liver Injury is Reduced in the Absence of Toll-like Receptor 4
}

\author{
Ziv Ben-Ari ${ }^{1,2,5}$ Orna Avlas ${ }^{2}$ Reut Fallach ${ }^{2}$ Hemda Schmilovitz-Weiss ${ }^{3,5}$ Yelena \\ Chepurko² Orit Pappo ${ }^{4}$ Edith Hochhauser ${ }^{2,5}$
}

${ }^{1}$ Liver Disease Center, Sheba Medical Center, Tel Hashomer, Ramat Gan ${ }^{2}$ Cardiac Research Laboratory, Felsenstein Medical Research Center, Rabin Medical Center, ${ }^{3}$ Gastroenterology Unit, Hasharon Hospital, Rabin Medical Center, ${ }^{4}$ Department of Histopathology, Beilinson Hospital, Rabin Medical Center, Petah Tiqwa, and ${ }^{5}$ Sackler School of Medicine, Tel Aviv University, Tel Aviv, *Orit Pappo and Edith Hochhauser are two last coauthors

\section{Key Words}

Tumor necrosis factor (TNF)- $\alpha \cdot$ Interleukin-1 $\beta \cdot$ Nuclear factor-kappaB (NF- $\kappa \mathrm{B}) \cdot$ Phosphorylated c-Jun $\mathrm{NH}$ 2-terminal kinase $(\mathrm{CJUN}) \cdot$ Ischemia reperfusion injury $\bullet$ TLR4, knockout • Liver

\begin{abstract}
Background/Aims: Toll-like receptor 4 (TLR4) is expressed on hepatic non-parenchymal cells and hepatocytes. Hepatic signaling through TLR4 is critical in the pathogenesis of ischemia reperfusion injury (IRI) and leads to the release of cytokines. The role of bone marrow-derived TLR4 in the early reperfusion stage is unclear. Methods: We used wild type mice (WT), TLR4deficient (TLR4ko) mice and chimeras to dissociate between the role of TLR4 expression in the liver (TLR4ko/WT) and in the immuno-hematopoietic system (WT/TLR4ko) in mouse hepatic IR injury model. Mice were subjected to in vivo partial IRI (70\% for 60 min). Results: Compared with WT IR livers, TLR4ko IRI mice (4 hours) showed a significant reduction in serum liver enzyme, hepatic TNF- $\alpha$ and interleukin- $1 \beta$ levels. Fewer apoptotic hepatocytes cells were identified by morphological criteria and immunohistochemistry for caspase-3. In TLR4ko mice, decreased hepatic CJUN and NF- $\kappa B$ expression during IRI was noted compared with WT mice. Chimeric mice having either TLR4 bone-marrow or non-bone marrow derived cells following IRI exhibited almost similar hepatic injury as WT mice in the immediate reperfusion stage. Conclusion: Both TLR4 bone marrow-derived and non-bone marrow-derived cells are necessary in the initial process of hepatic injury. Activating TLR4-dependent signaling is required for IRI. The absence of the TLR4 gene plays a pivotal role in reducing hepatic IR injury.
\end{abstract}




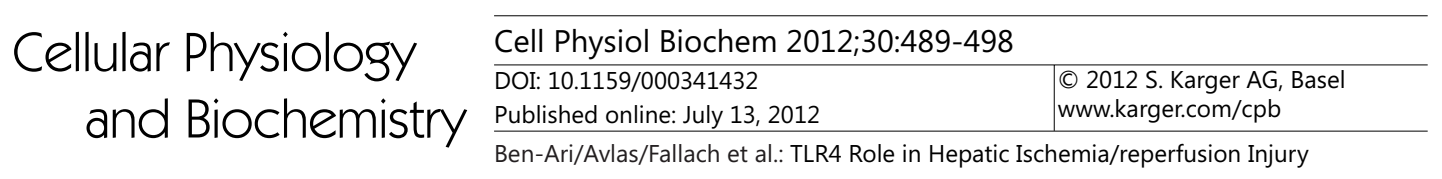

\section{Introduction}

Ischemia-reperfusion injury (IRI) is the main cause of both primary graft dysfunction (occurring in 10\%-30\% of grafts) and primary nonfunction of liver allograft (occurring in $5 \%$ of grafts) [1]. The latter is responsible for $81 \%$ of retransplantations during the first week after surgery $[1,2]$. Therefore, minimizing the adverse effects of IRI injury could increase the number of both suitable transplantation grafts and patients who successfully recover from liver transplantation. Although it is widely accepted that innate immunity holds a crucial role in the pathogenensis of liver IRI, the exact molecular mechanisms that induce IRI-related innate immune cell activation have not been fully elucidated to date [3, 4].

Recognition of many microbial toxins occurs through the activation of Toll-like receptors (TLR) that cause induction of the innate immune response [5-6]. The TLRs sense the invasion of pathogenic microorganisms or tissue damage by recognizing specific molecular patterns that are present in microbial products (pathogen-associated molecular pattern molecules) or endogenous molecules released by damaged tissues [7]. Toll-like receptor 4 (TLR4), is expressed on all kinds of liver cells and plays a key role in the sterile inflammatory cascade including hepatic IRI [8-10]. It is well established that the effects of cytokines released following TLR4 activation are dependent on the integration of the innate and adaptive immune systems [11]. Endogenous TLR ligands that present the dangerous signal may initiate an immune response in the absence of infection [5]. Hepatic IRI may well fit into such a system thus the role of TLR4 in the noninfectious settings can be evaluated. Hepatocyte derived TNF- $\alpha$ and IL- $1 \beta$ activated by the nuclear factor $\kappa B(N F-\kappa B)$ were implicated as important mediators of reperfusion injury in the liver [3,12]. Apart from NF-kB, several other intracellular signaling pathways are induced following IRI, including the c-Jun $\mathrm{N}$ terminal kinase (CJUN) [13]. CJUN was shown to mediate apoptotic programmed cell death

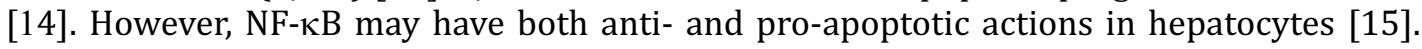
Since TLR4 is present on both hepatocytes and non parenchymal cells, we hypothesized that endogenous ligands from damaged hepatic ischemic cells can activate innate immunity via TLR4 signaling and may provide the initiating signals for the activation TLR4/NF- $\kappa B$ pathway, resulting in the downstream inflammatory storm. This study focuses on the alteration of liver necrotic and apoptotic damage following partial liver ischemia and reperfusion injury in TLR4 ko and wild type mice in relation to CJUN and NF- $\mathrm{\kappa B}$ activation. By using TLR4 chimeric mice, we demonstrate that TLR4 derived from non-parenchymal cells and from hepatocytes is responsible for recognizing the initial damage in ischemic hepatic cells and for activating TLR4-dependent signaling required for IR-induced hepatic apoptotic and necrotic injury.

\section{Materials and Methods}

\section{Animals and treatments}

TLR4ko mice (C57BL/10ScNJ; The Jackson Laboratory) are an inbred strain, homozygous for a spontaneous mutation resulting in a deletion allele Tlr4 $4^{\text {lps-del }}$. These mice and their wild-type controls C57BL/10 were the generous gift of Prof. Irun Cohen (Weizmann Institute, Israel).

All male mice were maintained in a pathogen-free facility and were fed pellet food and water ad libitum, until the start of the experiment (12 weeks old). All experiments were carried out in accordance with the guidelines of the Animal Care and Use Committee of the Felsenstein Medical Research Center and Tel Aviv University (Tel Aviv, Israel).

\section{General Experimental Protocols}

In vivo IRI model. A model of segmental (70\%) hepatic ischemia was used as previously described [16]. Mice were anesthetized by intra-peritoneal injection of chloral hydrate (10 mg/100 g body weight). After a midline laparotomy, all structures in the portal triad (hepatic artery, portal vein, and bile duct) to the left and median liver lobes were occluded for $60 \mathrm{~min}$ with a vascular atraumatic clamp. This method of partial hepatic ischemia prevented mesenteric venous congestion by permitting portal decompression through the right and caudate lobes. Reperfusion was initiated by removal of the clamp. 


\begin{tabular}{|c|c|c|}
\hline & Cell Physiol Biochem 2012;30:489-498 & \\
\hline and Rinchemistr & $\begin{array}{l}\text { DOI: 10.1159/000341432 } \\
\text { Published online: July 13, } 2012 \\
\end{array}$ & $\begin{array}{l}\text { O 2012 S. Karger AG, Basel } \\
\text { www.karger.com/cpb }\end{array}$ \\
\hline
\end{tabular}

General experimental protocols

Transgenic homozygotic knockout mice (TLR4ko) and WT mice (C57BL) adult male mice (weighing 25-28g) were each randomly allocated to 4 experimental groups ( $\mathrm{n}=10 \mathrm{each}$ ), as follows: 1) WT - sham operation, 2) WT- in vivo IRI, 3) TLR4ko - sham operation, 4) TLR4ko - in vivo IRI.

\section{Generation of chimeric mice}

Chimeric mice having either TLR4 bone-marrow or non-bone marrow derived cells were generated. C57Bl mice or TLR4ko were irradiated at $850 \mathrm{rad}$ (106 rad/min) using an X-ray irradiator (RadSource 2000, Alpharetta, GA, USA) and grafted with $30 \times 10^{6}$ whole bone marrow cells (BMC) suspended in $0.2 \mathrm{ml}$ PBS [17] into the lateral tail vein. To achieve TLR4 expression in the immune system, TLR4-ko mice ( $\mathrm{H} 2 \mathrm{~Kb}$, CD45.2) were grafted with BMC from wild type syngeneic donors (H2Kb, CD45.1) (WT/TLR4ko). b) To eliminate TLR4 expression in the immuno-hematopoietic system, WT mice (H2Kb, CD45.1) were grafted with BMC from syngeneic TLR4ko donors (H2Kb, CD45.2) (TLR4ko/WT). c) Control chimeras underwent transplantation and consisted of CD45.1 recipients and CD45.2 donors (WT/WT). Peripheral blood was collected from the lateral face vein, isolated by centrifugation over a Ficoll gradient (Cedarlane, Ontario, Canada) and washed. Chimerism was determined at 8-10 weeks after bone marrow transplantation, as the fractional expression of donor and host peripheral blood lymphocytes using mAbs against minor antigens CD45.1 (cloneA20, eBioscience, San Diego, CA, USA) and CD45.2 (clone104 eBioscience, San Diego, CA, USA) using a Vantage SE-II flow cytometer (Becton Dickinson). TLR4 expression was assayed using Alexa Fluor ${ }^{\circledR}$ 488 anti-mouse TLR4 (CD284) mAb as compared to an isotype control (mouse IGg1 mAb). Four chimeric mice were added to each above experimental group.

\section{Liver enzyme levels}

Serum $(0.5 \mathrm{ml})$ was collected at 4 hour post reperfusion and kept on ice until processed. Levels of aspartate transaminase (AST) and alanine transaminase (ALT) were determined in serum, in duplicate, using commercial kits, according to the manufacturer's protocols.

\section{Hepatic TNF- $\alpha$ and IL-1 $\beta$ level after IRI}

Hepatic cytokines levels were assessed using ELISA semi-kits for mouse TNF- $\alpha$ and mouse IL-1 $\beta$ (ELISA-Max, BioLegend, CA, USA). Cytokines in the hepatic ischemic lobes were measured using 100 $\mu \mathrm{g}$ of protein. Standard reference cytokines were provided by the manufacturer. Assays were done in duplicate with a micro titer plate reader (450-nm wavelength). Values are reported as picograms per milligram of protein [17].

\section{Quantitative RT-PCR}

Total RNA was purified from the ischemic lobes of the liver by using TRIzol (Ambion, USA) according to the manufacturer's instructions. The quantity of total RNA was determined by OD260 measurements. cDNA was synthesized from total RNA using the TaqMan High Capacity cDNA Reverse Transcription Kit (Applied Biosystems; Foster City, CA, USA) according to the manufacturer's protocol. Quantitative real-time PCR analysis (Taqman) for mouse TLR4 was performed using the ABI 7000 Sequence Detection system (Applied Biosystems; Foster City, CA, USA). A total of $2 \mu \mathrm{l}$ of cDNA was amplified with $10 \mu \mathrm{l}$ TaqMan Universal PCR Master MIX, $1 \mu \mathrm{l}$ TaqMan SNP genotyping assays and $7 \mu \mathrm{L}$ DEPC. PCR amplification was performed consisting of $2 \mathrm{~min}$ at $50^{\circ} \mathrm{C}, 10 \mathrm{~min}$ at $95^{\circ} \mathrm{C}$ and 40 cycles of $15 \mathrm{sec}$ at $60^{\circ} \mathrm{C}$. All the samples were normalized to an endogenous gene, mouse TATA-box [17].

\section{Pathological Evaluation}

Specimens from the ischemic liver (left lateral or median lobes) in all groups were fixed in formalin, embedded in paraffin, and stained with hematoxylin-eosin. Pathological findings were assessed by one of the author (OP) blinded to the group allocations.

\section{Immunohistochemistry for caspase-3}

Apoptotic hepatocytes in ischemic lobes were identified using Caspase-3 immunohistochemistry. For activated caspase- 3 immunostaining, $5 \mathrm{~lm}$ sections were dewaxed and hydrated through graded ethanols, cooked in $25 \mathrm{mM}$ citrate buffer at $\mathrm{pH} 6.0$ in a pressure cooker at $115^{\circ} \mathrm{C}$ for $3 \mathrm{~min}$ (decloaking chamber; Biocare Medical,), transferred into boiling deionized water, and let to cool for $20 \mathrm{~min}$. After $5 \mathrm{~min}$ of treatment 


\section{Cellular Physiology Cell Physiol Biochem 2012;30:489-498 \begin{tabular}{ll|l} 
and BiOChemistry & DOI: 10.1159/000341432 & $\begin{array}{l}\text { C 2012 S. Karger AG, Basel } \\
\text { www.karger.com/cpb }\end{array}$ \\
\cline { 2 - 3 }
\end{tabular}}

Fig. 1. In WT mice following induction of IRI, serum AST and ALT levels increased significantly compared with sham operated $(*)$ mice or TLR4ko mice $(+)$, $(\mathrm{p}<$ 0.05). (Fig. 1A). Liver IRI induced significant upregulation of hepatic TLR4 gene expression, 4 hours following treatment (Fig. 1B) $\left({ }^{*} \mathrm{p}<0.05\right)$. The hepatic Il-1 $\beta$ level and TNF- $\alpha$ increased significantly in WT mice following the induction of IRI compared with sham operated mice $(*)$ or TLR4ko mice $(+)(\mathrm{p}<0.05)$ (Fig. 1C,D). (n=10 in each group).

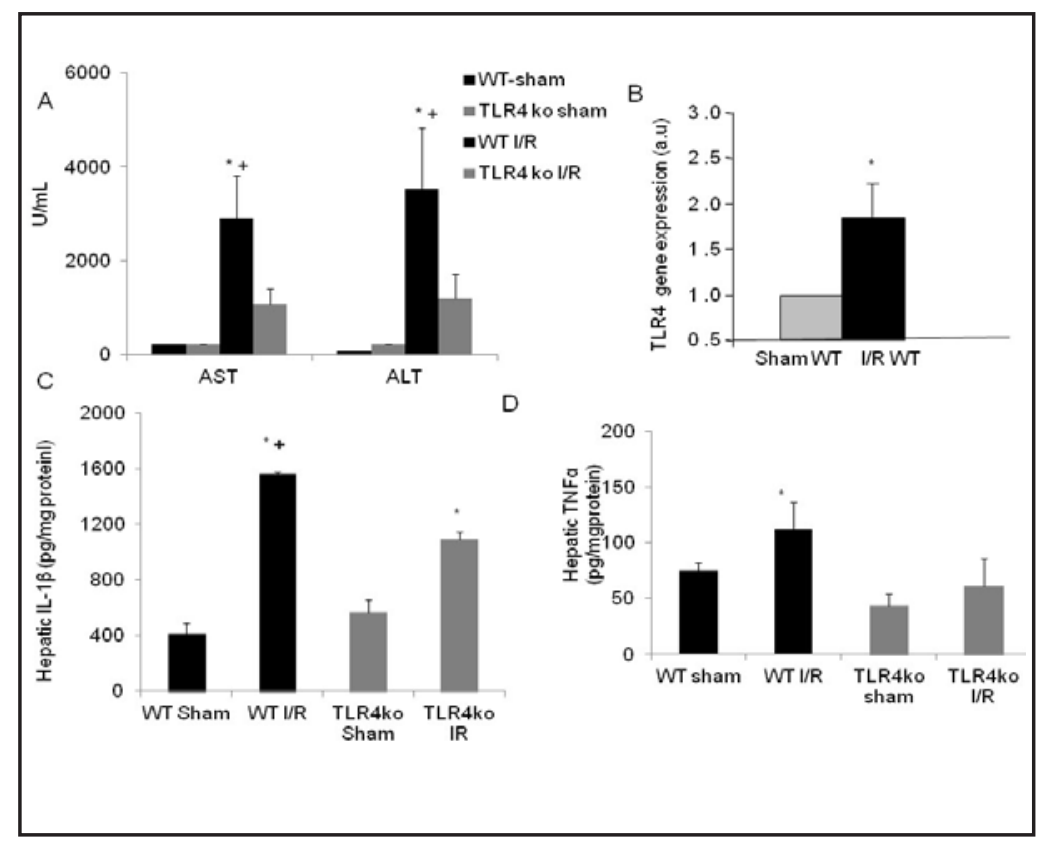

in $3 \% \mathrm{H}_{2} \mathrm{O}_{2}$, the slides were incubated with rabbit polyclonal activated caspase-3 (Cell Signaling) antibodies diluted 1:100 in CAS-Block (Zymed) for $3 \mathrm{~h}$ at room temperature or overnight at $4{ }^{\circ} \mathrm{C}$, washed 3 times with Optimax (HK583;Biogenex), incubated for 30 min with antirabbit Envision+ (K4007, Dako, Copenhagen, Denmark), and developed with 3,30-diaminobenzidine or 3-amino,9-ethylcarbazole.

Western blot analysis of liver tissue

Liver tissue samples (20 mg) were homogenized in lysis buffer and quantified for protein levels using a commercial assay (Bio-Rad). Liver extracts ( $30 \mu \mathrm{g}$ protein/lane) were electrophoresed and subjected to SDSPAGE under reducing conditions using $10 \%$ polyacrylamide gels. Proteins were transferred to nitrocellulose membranes and probed with the appropriate antibodies. Mouse monoclonal antibodies directed against the phosphorylated c-Jun NH2-terminal kinase [c-Jun(cc45)], rabbit anti-IкBa ( the inhibitory protein of NF$\mathrm{kB}$ ) and $\alpha$ sarcomeric actin (used as loading control) polyclonal antibody were purchased from Santa-Cruz Biotechnology, Inc. (Santa Cruz, CA); rabbit anti-JUN polyclonal antibody was purchased from Sigma Chemical Co. (St. Louis, MO). Detection was carried out by horseradish peroxidase-conjugated secondary antibodies and enhanced chemiluminescence. Peroxidase-conjugated goat anti-mouse IgG was purchased from Jackson ImmunoResearch Laboratories Inc. (West Grove, PA) and peroxidase-conjugated goat anti-rabbit IgG was purchased from Sigma Chemical Co. (St. Louis, MO). Quantification of enhanced chemiluminescence was carried out by VersaDoc Imaging System (Bio-Rad Laboratories, Inc., Hercules, CA).

\section{Statistical analysis}

Results are expressed as means \pm standard deviation. Differences between groups were assessed using the analysis of variance (ANOVA) with repeated measurements using the multiple comparison option of Duncan.

\section{Results}

\section{Liver enzymes}

In WT mice following induction of IRI, serum AST and ALT levels increased significantly compared with sham operated mice $(p<0.05)$. In TLR4ko mice, the increase in serum liver enzymes level was significantly lower than in WT mice ( $p<0.05$ ) (Fig. 1A). Thus, knocking out the TLR4 gene had a protective effect during partial hepatic IRI. 


\begin{tabular}{rl|l} 
Cellular Physiology & Cell Physiol Biochem 2012;30:489-498 \\
\cline { 2 - 2 } $\begin{array}{l}\text { DOI: 10.1159/000341432 } \\
\text { and Biochemistry }\end{array}$ & $\begin{array}{l}\text { Published online: July 13, 2012 } \\
\text { Buww.karger.com/cpb }\end{array}$ \\
\cline { 2 - 2 } Ben-Ari/Avlas/Fallach et al.: TLR4 Role in Hepatic Ischemia/reperfusion Injury
\end{tabular}

Fig. 2. Histological findings following induction of IRI in WT mice using H\&E staining demonstrated ballooning hydropic degeneration of hepatocytes, congestion in central areas, many acidophilic bodies and groups of apoptotic hepatocytes in the ischemic lobe (shown with arrows, Fig. 2A). In contrast, in TLR4ko mice better preserved hepatic architecture, less ballooning degeneration, very few acidophilic bodies and rare apoptotic hepatocytes were noted (shown with arrows), Fig. 2B). Using immunohistochemistry for caspase-3. Many apoptotic hepatocytes were observed (Fig. 2C). In the TLR4ko livers following IRI induction, fewer hepatocytes stained for the activated form of caspase-3, (Fig. 2D).

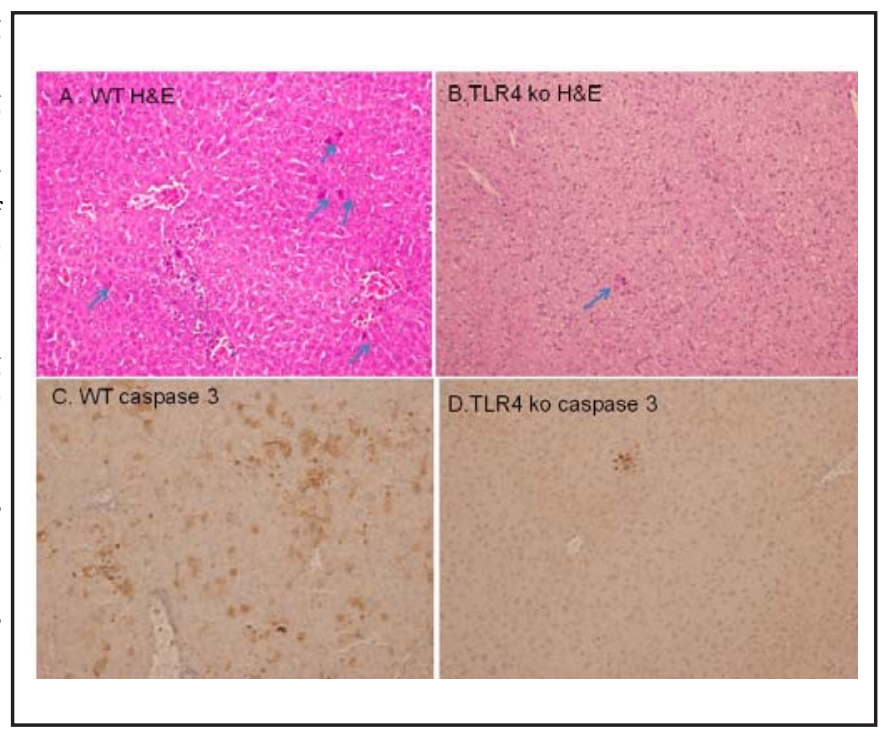

Fig. 3. Western blot analysis of liver tissue following the induction of IRI demonstrated in WT mice that I $\kappa \mathrm{B}$ (inhibitory proteins of NF- $\kappa B$ ) hepatic expression was significantly lower compared with sham operated mice or TLR4ko mice in the ischemic lobe. $(p<0.05)$ (Fig. 3A) .In WT mice following the induction of IRI, phosphorylated CJUN hepatic expression was significantly higher compared with sham operated mice. In TLR4ko mice the phosphorylated CJUN hepatic expression was significantly lower compared with WT mice $(\mathrm{p}<0.05)$, (Fig. 3B).

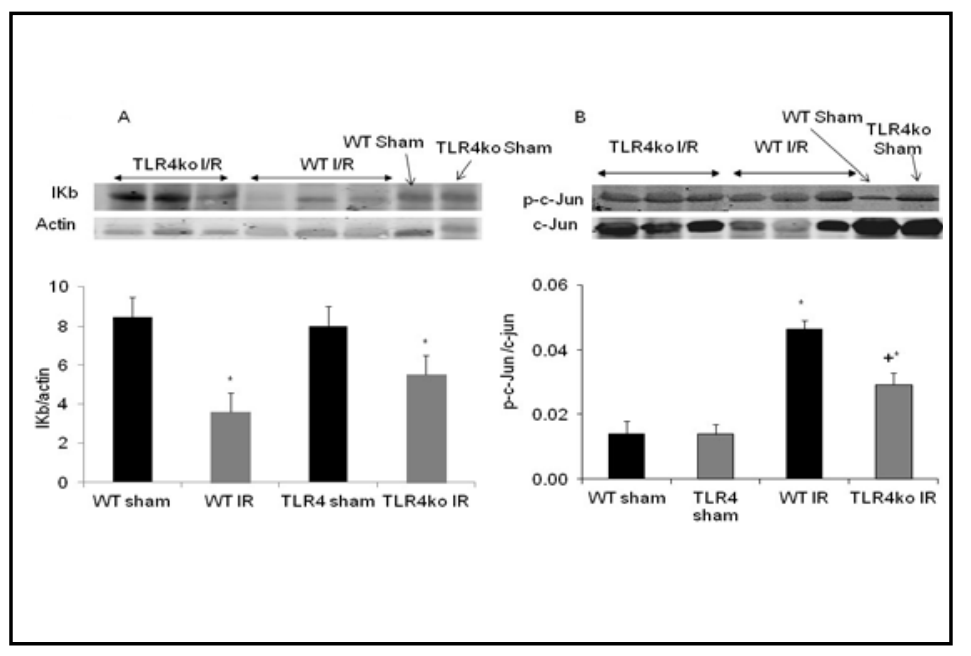

Expression of TLR4 following IRI

Liver IRI induced the significant up-regulation of hepatic ischemic lobes TLR4 gene expression, 4 hours following treatment (Fig. 1B) $(\mathrm{p}<0.05)$.

\section{Hepatic TNF- $\alpha$ and IL-1 $\beta$ level following induction of IRI}

To determine whether TLR4 might play a role in the in vivo induction of ischemic hepatic proinflammatory cytokines, TNF- $\alpha$ and IL- $1 \beta$ hepatic levels were assessed in WT and TLR4ko mice. The hepatic Il-1 $\beta$ level increased significantly in WT mice following the induction of IRI compared with sham operated mice. In TLR4ko mice hepatic Il-1 $\beta$ level was significantly lower compared with WT mice ( $p<0.05$ ) (Fig. 1C). The hepatic TNF- $\alpha$ level in the ischemic lobes increased significantly in WT mice following the induction of IRI compared with sham operated mice. In TLR4ko mice, hepatic TNF- $\alpha$ level was significantly lower compared with WT mice ( $p<0.05)$ (Fig. 1D). Thus, knocking out TLR4 gene had a beneficial effect during partial hepatic IRI.

\section{Histologic findings}

H\&E staining. Histological findings in the ischemic lobes following induction of IRI in WT mice using H\&E staining demonstrated ballooning hydropic degeneration of hepatocytes, congestion in central areas, many acidophilic bodies and groups of apoptotic hepatocytes (Fig. 2A). In contrast, in TLR4ko mice better preserved hepatic architecture, less ballooning 


\begin{tabular}{rl|l} 
Cellular Physiology & Cell Physiol Biochem 2012;30:489-498 \\
\cline { 2 - 2 } $\begin{array}{l}\text { DOI: 10.1159/000341432 } \\
\text { and Biochemistry }\end{array}$ & $\begin{array}{l}\text { Published online: July 13, 2012 } \\
\text { Buww.karger.com/cpb }\end{array}$ \\
\cline { 2 - 2 } Ben-Ari/Avlas/Fallach et al.: TLR4 Role in Hepatic Ischemia/reperfusion Injury
\end{tabular}

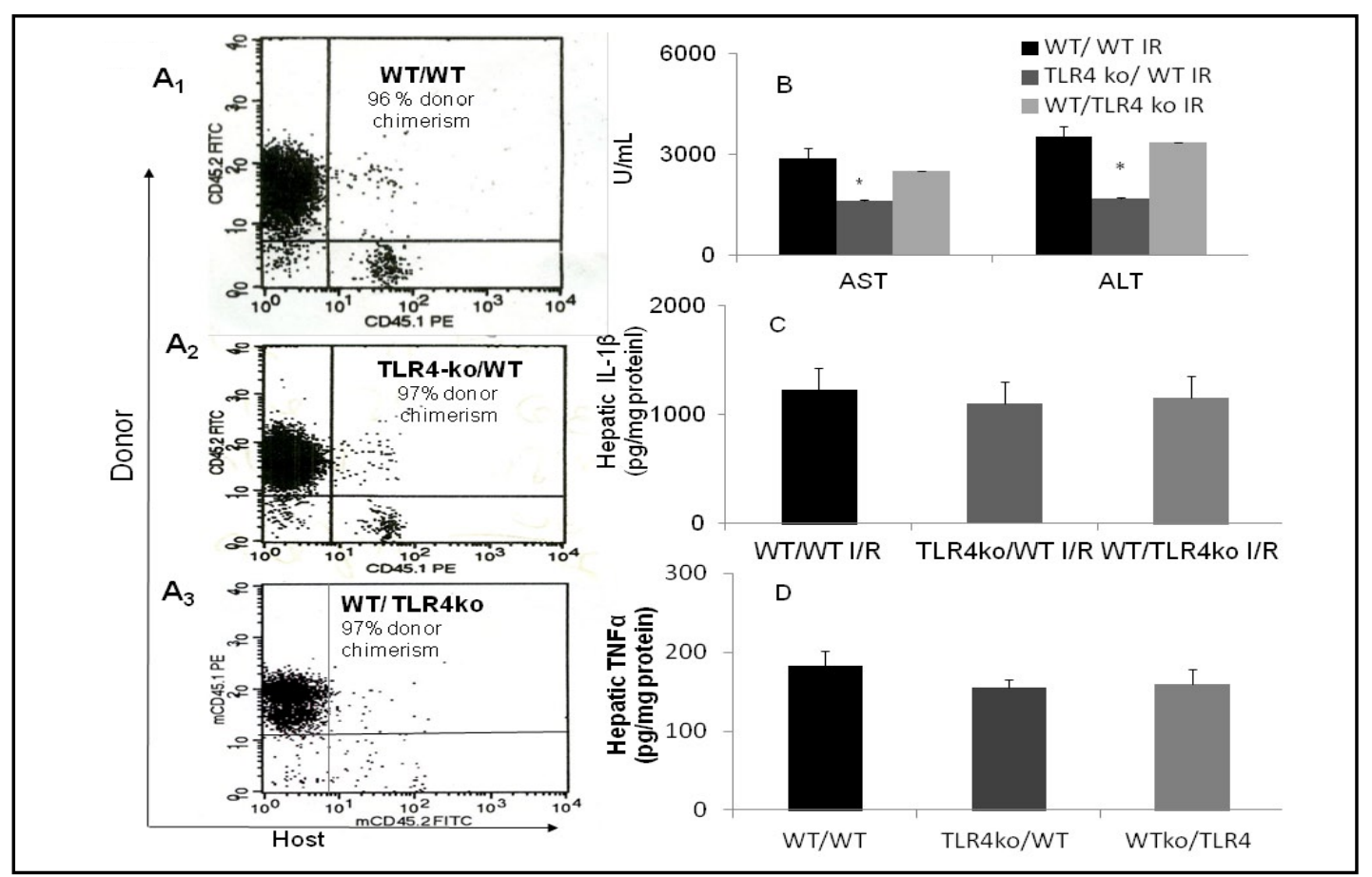

Fig. 4. Chimeric mice that expressed TLR4 either in the ischemic lobe of the liver or in peripheral blood mononuclear cells (BMC) were used (Fig. 4A1-A3). A control group consisted of syngeneic transplants in WT mice using two strains different in one minor antigen (CD45.1, CD45.2) to account for the effects of radiation and bone marrow transplantation (Fig. 4 A1-A3). Representative FACS analysis plots of the 3 experimental groups are presented: WT/WT - WT recipients (CD45.1) transplanted with BMC from WT donors (CD45.2); TLR4ko/WT - WT recipients (CD45.1) transplanted with BMC from TLR4-ko donors (CD45.2); WT/TLR4ko - TLR4ko recipients (CD45.2) transplanted with BMC from WT donors (CD45.1). Liver enzymes and hepatic TNF- $\alpha$ and IL-1 $\beta$ level after IRI in chimeras in the ischemic lobe (Fig. 4B-D). Chimeric mice having TLR4 in the BMC had an increase in serum liver enzyme and hepatic cytokine levels similar to WT/WT mice following IRI. However similar hepatic cytokines levels were found in all chimeric groups.

degeneration, very few acidophilic bodies and rare apoptotic hepatocytes were noted (Fig. 2B).

Immunohistochemistry for caspase-3

Sections from WT ischemic liver lobes following the induction of IRI were highly positively stained for the activated form of caspase-3. Many apoptotic bodies (single and in clusters) were observed. Diffused positive nuclear and cytoplasmic staining in $40 \%$ of hepatocytes was noted (Fig. 2C). In the TLR4ko livers following IRI induction, fewer hepatocytes stained for the activated form of caspase-3 (Fig. 2D).

\section{Effect of IRI on the hepatic expression of phosphorylated CJUN and NF- $\kappa B$}

Western blot analysis of liver tissue following the induction of IRI demonstrated in WT mice that I $\mathrm{KB}$ (inhibitory proteins of NF- $\kappa \mathrm{B}$ ) hepatic expression was significantly lower (2.5fold) compared with sham operated mice. In TLR4ko mice the IKB hepatic expression was significantly higher (by 33\%) $(\mathrm{p}<0.05)$ compared with WT mice (Fig. 3A).

In WT mice following the induction of IRI, phosphorylated CJUN hepatic expression was significantly higher (3-fold) compared with sham operated mice. In TLR4ko mice the phosphorylated CJUN hepatic expression was significantly lower compared with WT mice (by 30\%) $(\mathrm{p}<0.05)$ (Fig. 3B). 


\section{Cellular Physiology $\quad$ Cell Physiol Biochem 2012;30:489-498

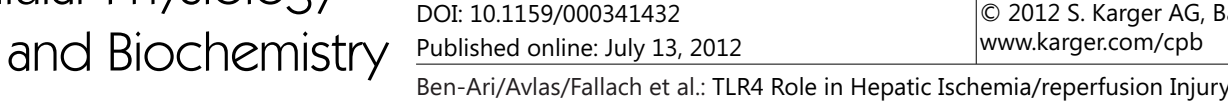

Fig. 5. A-B: Histological findings and western blot analysis of liver tissue following induction of IRI in chimeras. H\&E staining demonstrated in TLR4ko/ WT mice ballooning and hydropic degeneration of hepatocytes compared with WT/TLR4-ko (shown with arrow). C-D: Hepatic I $\kappa \mathrm{B}$ and phosphorylated CJUN, the activation of both hepatic I $\mathrm{B} B$ and phosphorylated CJUN in the ischemic liver was similar in all chimeric groups. $(n=4$ in each group).

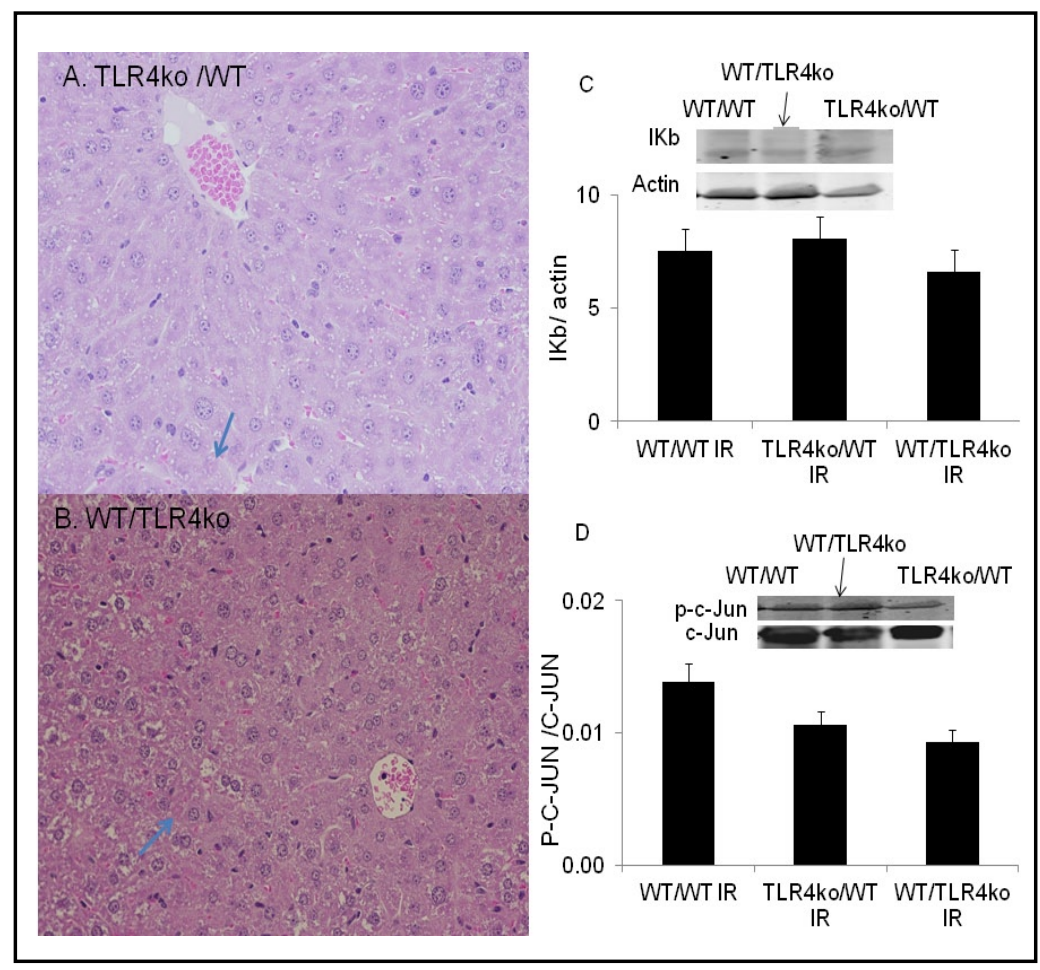

\section{Chimeric mice}

To investigate the role played by hepatocytes and resident macrophages following ischemic challenge, we used chimeric mice that expressed TLR4 either in the liver or in peripheral blood mononuclear cells (BMC) (Fig. 4A1-A3). A control group consisted of syngeneic transplants in WT mice using two strains different in one minor antigen (CD45.1, CD 45.2) to account for the effects of radiation and bone marrow transplantation. Full donor chimerism $(>95 \%)$ was measured 8-10 weeks post transplantation. Representative FACS analysis plots of the 3 experimental groups are presented in Fig. 4A1-A3: WT/WT - WT recipients (CD45.1) transplanted with BMC from WT donors (CD45.2); TLR4ko/WT - WT recipients (CD45.1) transplanted with BMC from TLR4ko donors (CD45.2); WT/TLR4ko TLR4ko recipients (CD45.2) transplanted with BMC from WT donors (CD45.1).

Liver enzymes, hepatic $T N F-\alpha$ and IL-1 $\beta$ level and histological findings after IRI in chimeras

Chimeric mice having TLR4 in the BMC had an increase in serum liver enzyme and hepatic cytokine levels similar to WT/WT mice following IR. However similar hepatic cytokines levels were found all chimeric groups (Fig. 4B-D). Histological findings following induction of IRI in chimeric mice using H\&E staining demonstrated in TLR4ko/ WT mice ballooning and hydropic degeneration of hepatocytes compared with WT/TLR4ko (Fig. 5A-B). The activation of both hepatic IKB and phosphorylated CJUN in the ischemic liver was similar in all chimeric groups having TLR4 in the BMC or in the liver and lower than chimeric control mice WT/WT (Fig. 5C-D). Thus, TLR4 activation in hepatocytes, in non parenchymal cells and in BMC took place in the immediate phase of the release of proinflamatory cytokines.

\section{Discussion}

In the present study we demonstrated the significant contribution of hepatic TLR4 to the deleterious effects of hepatic IRI. We showed that following the induction of IRI in WT mice, the severe hepatic damage was associated with a significant increase in TLR4 mRNA expression whereas significant hepatic injury was observed in LTR4ko mice. Following 


\section{Cellular Physiology Cell Physiol Biochem 2012;30:489-498 \\ \begin{tabular}{ll|l} 
and Biochemistry & DOI: 10.1159/000341432 & $\begin{array}{l}\text { C 2012 S. Karger AG, Basel } \\
\text { www.karger.com/cpb }\end{array}$ \\
\cline { 2 - 3 } & Published online: July 13, 2012 & Ben-Ari/Avlas/Fallach et al.: TLR4 Role in Hepatic Ischemia/reperfusion Injury
\end{tabular}}

IRI induction in WT mice, severe hepatic damage was manifested by increased serum liver enzymes and histologicaly by the typical ballooning hydropic degeneration of hepatocytes, congestion in central areas and many groups of apoptotic hepatocytes exhibiting caspase 3 activation. In addition, increased hepatic TNF- $\alpha$ and IL-1 $\beta$ level as well as increased hepatic NFKB and the phosphorylated CJUN expression was noted. The absence of TLR4 in our hepatic IRI model was associated with significantly reduced hepatic injury. Our findings are compatible with other published studies in which absence of TLR4 prevented the downstream signaling that led to severe hepatic injury following ischemia/reperfusion [18-23]. Wild-type chimeric mice bearing TLR4ko hemopoietic cells were protected from hepatic IRI and exhibited decreased enzymes release levels (AST and ALT) but similar CJUN and NF- $\mathrm{KB}$ activation compared with WT chimeric mice transplanted with their own bone marrow or TLR4ko mice transplanted with WT bone marrow. Since all chimeric mice were not protected from the hepatic IRI as theTLR4ko mice, we conclude that both hepatocites and BMC participated in IRI but the contribution of the hepatocytes to the process was less than the BMC.

Lipopolysaccharide (LPS) as a TLR4 ligand that can activate TLRs, triggers a macrophage-, neutrophil- and complement-mediated inflammatory reaction relative to IRI [22]. In our recently published study [24] we analyzed TLR2 and TLR4 mRNA expression in Huh7 cell culture (lacking nonparenchymal cells) that was incubated with GalN/LPS for gene expression. While TLR4 mRNA was 3 times higher in GalN/LPS treated cells, TLR2 which is also known to be activated by LPS, was elevated only 1.7 times, suggesting that TLR4 is the main player in a model of fulminant hepatitis and that TLR2 which is weakly activated, has only a minor role [25]. Experimental data also provide evidence that TLR4 signaling is probably involved in the cascade of liver IRI [20]. In an established murine model of liver warm ischemia followed by reperfusion, TLR4 but not TLR2, was specifically required in initiating the IRI cascade. TLR4 knockout mice livers were protected from IRI as was manifested by liver enzymes, histology and the local induction of proinflammatory cytokines/chemokines [TNF- $\alpha$, IL-6, IFN-inducible protein]. Wang et al [21] who used TLR4 deficient and WT mice demonstrated that TLR4 activation causes liver IR injury through TNF- $\alpha$ release. Apart from the host, TLR expression in the donor organ may also affect the IRI sequel following liver transplantation. Orthotopic liver transplantations (OLTs) were performed in groups of WT and TLR4ko mice [19]. TLR4-deficient OLTs that were transplanted into WT or TLR4ko recipients, suffered significantly less hepatocellular damage compared to WT OLTs. Disruption of TLR4 signaling in OLTs decreased several inflammatory pathways such as local neutrophil sequestration, CD4+ T cell infiltration, CXCL10 and ICAM-1, as well as TNF- $\alpha$, IL-1 $\beta$, IL-2 and IFN- $\gamma$. These outcomes indicate that not only the host's, but also the donor organ's TLR4 complex functionality plays a key role in the mechanism of hepatic IRI after transplantation $[19,23]$.

Regarding the origin of the ligands that are responsible for activating TLR4 at the hepatic IR injuri cascade, these most likely are host-derived. Zhai et al. [18] provided definitive evidence that endogenous TLR4 ligands are critical in the pathogenesis of liver IRI. It was shown that the endotoxin blockade failed to protect mouse livers from IRI and that liver perfusate contained LPS-independent, heat-sensitive protein molecules that activated macrophages to produce TNF- $\alpha$ through the TLR4 but not the TLR2 pathway. Using the same chimeric mice model, Tsung et al. [26] concluded that hepatic IRI involves functional TLR4 signaling in nonparenchymal cells. They explained that WT chimeric mice bearing TLR4 mutant hemopoietic cells and TLR4 mutant mice transplanted with their own bone marrow-derived cells were protected from hepatic IRI and exhibited decreased c JNK and NF- $\mathrm{KB}$ activation compared with WT chimeric mice transplanted with their own bone marrow [26]. Our results are similar to those reported by Tsung et al. regarding enzymes release but our findings include also CJUN and NF- $\kappa B$ signaling pathway activation and histological description. Our results are also similar to those reported by Hui et al., who also generated TLR4 chimeric mice that underwent hepatic IRI [25]. They found that mutation of TLR4 on bone-marrow or non-bone marrow derived cells reduced hepatic IRI via cytokine release and neutrophil infiltration [25]. In our study, both chimeric mice groups expressing 


\section{Cellular Physiology Cell Physiol Biochem 2012;30:489-498 \\ \begin{tabular}{ll|l} 
and Biochemistry & DOI: 10.1159/000341432 & $\begin{array}{l}\text { C 2012 S. Karger AG, Basel } \\
\text { www.karger.com/cpb }\end{array}$ \\
\cline { 2 - 3 } & Published online: July 13, 2012 & Ben-Ari/Avlas/Fallach et al.: TLR4 Role in Hepatic Ischemia/reperfusion Injury
\end{tabular}}

TLR4 in either the hematopoetic system or in the liver had similar increased hepatic CJUN and NF- $\kappa B$ activation. The lack of TLR4 expression in both systems was protective against hepatic IRI. Moreover, we have recently shown that following the administration of LPS to chimeric mice lacking TLR4 in their hematopoietic system (TLR4ko to WT) both TNF- $\alpha$ and IL-1 $\beta$ were slightly, but significantly elevated following LPS injected i.p. or following the induction of myocardial IR injury [17]. It is notable that the same group using chimeric mice subjected to hemorrhagic shock and LPS [27] reported that TLR4ko mice receiving WT bone marrow and TLR4- $\mathrm{C} 3 \mathrm{H} / \mathrm{HeJ}$ mutant mice receiving mutant bone marrow, responded to the injury in a similar pattern and protection was afforded to mice lacking functional TLR4. This demonstrates that functional TLR4 is required in bone-marrow-derived cells and parenchymal cells for an optimal inflammatory response to injury.

Based on the data presented above, it can be suggested that therapeutic modulation of TLR4, may alter the natural course of hepatic IRI and might offer clinical benefits for patients undergoing liver transplantation [23]. Disruption of TLR4 signaling decreases several pathways leading to different activated proteins thus resulting in less cell damage. These results provide the rationale to locally modify innate TLR4 signaling in the donor organ before transplantation to more efficiently control the adaptive post-transplantation IR injury-dependent responses. TLR4 can initiate an exaggerated proinflammatory response early after IRI injury, contributing to hepatic injury and dysfunction. The function of TLR4 extends beyond host defense against invading pathogens; TLR4 seems to be a cellular sensor for acute hepatic damage that controls innate immunity and tissue integrity. Gene silencing of TLR4 prior to the induction of ischemia resulted in the inhibition of TLR4 expression and reduction of liver IRI [28]. It seems that both pharmacological or gene TLR4 inhibition may alleviate tissue injury in the early stage following the induction of ischemia. Thus, hepatocytes TLR4 expression and inflammatory cells plays a critical role in the induction of liver dysfunction.

In conclusion, both TLR4 bone marrow and non-bone marrow derived cells are necessary in the initial process of hepatic ischemia injury at 4 hours following reperfusion. TLR4 has an important role in the regulation of hepatic IRI. Down-regulation of TLR4 expression and function plays a pivotal role in hepatic IRI. The TLR4 gene may serve as a potential target for therapeutic intervention in hepatic IRI during liver transplantation, liver resection and trauma.

\section{References}

1 Clavien PA, Harvey PR, Strasberg SM: Preservation and reperfusion injuries in liver allografts. An overview and synthesis of current studies. Transplantation 1992;53:957-978.

2 Jaeschke H: Preservation injury: Mechanisms, prevention and consequences. J Hepatol 1996;25:774-780.

3 Kojima Y, Suzuki S, Tsuchiya Y, Konno H, Baba S, Nakamura S: Regulation of pro-inflammatory and antiinflammatory cytokine responses by Kupffer cells in endotoxin-enhanced reperfusioninjury after total hepatic ischemia. Transpl Int 2003;16:231-240.

4 Nathan C: Points of control in inflammation. Nature 2002;420: 846-852.

5 Seki E, Brenner DA: Toll-like receptors and adaptor molecules in liver: update. Hepatology 2008;48:322335.

6 Werling D, Jungi TW: Toll-like receptors linking innate and adaptive immune response. Vet Immunol Immunopathol 2003;91:1-12.

$7 \quad$ Akira S, Takeda K: Toll-like receptor signalling. Nat Rev Immunol 2004;4:499-511.

8 Wang H, Li ZY, Wu HS, Wang Y, Jiang CF, Zheng QC, Zhang JX: Endogenous danger signals trigger hepatic ischemia/reperfusion injury through toll-like receptor 4/nuclear factor-kappa B pathway. Chin Med J (Engl) 2007;120:509-514. 


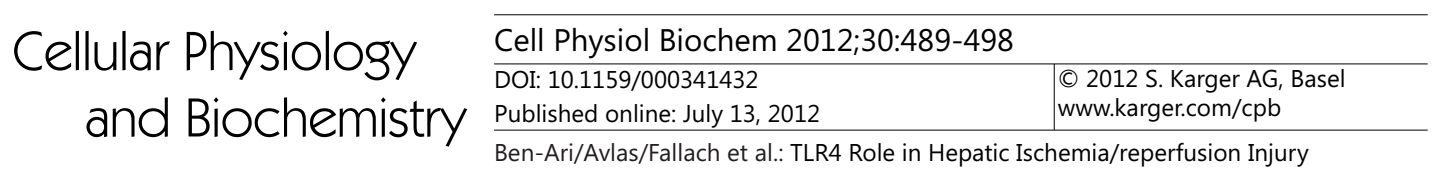

9 Uhrig A, Banafsche R, Kremer M, Hegenbarth S, Hamann A, Neurath M, Gerken G, Limmer A, Knolle PA. Development and functional consequences of LPS tolerance in sinusoidal endothelial cells of the liver. J Leukoc Biol 2005;77:626-633.

10 Tsung A, Hoffman RA, Izuishi K, Critchlow ND, Nakao A, Chan MH, Lotze MT, Geller DA, Billiar TR: Hepatic ischemia/reperfusion injury involves functional TLR4 signaling in non-parenchymal cells. J Immunol 2005;175:7661-7668.

11 Wu J, Meng Z, Jiang M, Zhang E, Trippler M, Broering R, Bucchi A, Krux F, Dittmer U, Yang D, Roggendorf M, Gerken G, Lu M, Schlaak JF: Toll-like receptor-induced innate immune responses in non-parenchymal liver cells are cell type-specific. Immunology 2010;129:363-374.

12 Medvedev AE, Kopydlowski KM, Vogel SN: Inhibition of lipopolysaccharide-induced signal transduction in endotoxin-tolerized mouse macrophages: dysregulation of cytokine, chemokine, and toll- like receptor 2 and 4 gene expression. J Immunol 2000;164:5564-5574.

13 Georgiev P, Dahm F, Graf R, Clavien PA: Blocking the path to death: Antiapoptotic molecules in ischemia/ reperfusion injury of the liver. Curr Pharm Des 2006;12:2911-21.

14 Uehara T, Bennett B, Sakata ST, Satoh Y, Bilter GK, Westwick JK, Brenner DA: JNK mediates hepatic ischemia reperfusion injury. J Hepatol 2005;42: 850-859.

15 Fan C, Yang J, Engelhardt JF: Temporal pattern of NFkappaB activation influences apoptotic cell fate in a stimuli-dependent fashion. J Cell Sci 2002;115:4843-4853.

16 Selzner N, Selzner M, Jochum W, Clavien PA: Ischemic preconditioning protects the steatotic mouse liver against reperfusion injury: an ATP dependent mechanism. J Hepatol 2003;39:55-61.

17 Fallach R, Shainberg A, Avlas O, Fainblut M, Chepurko Y, Porat E, Hochhauser E: Cardiomyocyte Toll-like receptor 4 is involved in heart dysfunction following septic shock or myocardial ischemia. J Mol Cell Cardiol 2010;48:1236-1244.

18 Zhai Y, Qiao B, Shen XD, Gao F, Busuttil RW, Cheng G, Platt JL, Volk HD, Kupiec-Weglinski JW: Evidence for the pivotal role of endogenous toll-like receptor 4 ligands in liver ischemia and reperfusion injury. Transplantation 2008;85:1016-1022.

19 Shen XD, Ke B, Zhai Y, Gao F, Tsuchihashi S, Lassman CR, Busuttil RW, Kupiec-Weglinski JW: Absence of tolllike receptor 4 (TLR4) signaling in the donor organ reduces ischemia and reperfusion injury in a murine liver transplantation model. Liver Transpl 2007;13:1435-1443.

20 Zhai Y, Shen XD, O'Connell R, Gao F, Lassman C, Busuttil RW, Cheng G, Kupiec-Weglinski JW: Cutting edge: TLR4 activation mediates liver ischemia/reperfusion inflammatory response via IFN regulatory factor 3dependent MyD88-independent pathway. J Immunol 2004;173:7115-7119.

21 Wang L, Xu JB, Wu HS, Zhang JX, Zhang JH, Tian Y, Wang CY: The relationship between activation of TLR4 and partial hepatic ischemia/reperfusion injury in mice. Hepatobiliary Pancreat Dis Int 2006;5:101-104.

22 Takeda K, Kaisho T, Akira S: Toll-like receptors. Annu Rev Immunol 2003;21:335-376.

23 Katsargyris A, Klonaris C, Alexandrou A, Giakoustidis AE, Vasileiou I, Theocharis S: Toll-like receptors in liver ischemia reperfusion injury: a novel target for therapeutic modulation?. Expert Opin Ther Targets 2009;13:427-442.

24 Ben Ari Z, Avlas O, Pappo O, Zilbermints V, Cheporko Y, Bachmetov L, Zemel R, Shainberg A, Sharon E, Grief F, Hochhauser E: Reduced hepatic injury in Toll-Like Receptor 4-Deficient mice following d-galactosamine/ lipopolysaccharide-induced fulminant hepatic failure. Cell Physiol Biochem 2012;29:41-50.

25 Hui W, Jinxiang Z, Heshui W, Zhuoya L, Qichang Z: Bone marrow and non-bone marrow TLR4 regulates hepatic ischemia/reperfusion injury. Biochem Biophys Res Commun 2009;389:328-332.

26 Tsung A, Hoffman RA, Izuishi K, Critchlow ND, Nakao A, Chan MH, Lotze MT, Geller DA, Billiar TR: Hepatic ischemia/reperfusion injury involves functional TLR4 signaling in nonparenchymal cells. J Immunol 2005; 175:7661-7668.

27 Mollen KP, Levy RM, Prince JM, Hoffman RA, Scott MJ, Kaczorowski DJ, Vallabhaneni R, Vodovotz Y, Billiar TR: Systemic inflammation and end organ damage following trauma involves functional TLR4 signaling in both bone marrow-derived cells and parenchymal cells. J Leukoc Biol 2008;83:80-88.

28 Jiang N, Zhang X, Zheng X, Chen D, Zhang Y, Siu LK, Xin HB, Li R, Zhao H, Riordan N, Ichim TE, Quan D, Jevnikar AM, Chen G, Min W: Targeted gene silencing of TLR4 using liposomal nanoparticles for preventing liver ischemia reperfusion injury. Am J Transplant 2011;11:1835-1844. 